\title{
Mito e imaginário em Saciologia goiana, de Gilberto Men- DONÇA TELES
}

VANDERLEI KROIN*

Antonio Donizeti da CRUZ**

\section{RESUMO}

A proposta deste trabalho é explorar a figura mítica do Saci na obra Saciologia goiana, de Gilberto Mendonça Teles. Esse ser, que faz parte do folclore, consta nas lendas e histórias orais. Além do mais, está arraigado no imaginário popular brasileiro e é mote desse livro de Teles, o qual apresenta uma verdadeira sociologia do Saci, trazendo imagens desse personagem mítico em diálogo com o popular e o erudito. Imagens que estão salpicadas de erotismo, de crítica social, de sátira, além de intertextualidade e alusões a outros poetas, em um rico diálogo que aproxima o sertão goiano com outros espaços. Nesse livro, repleto de neologismos, alusões, experimentações, há o encontro do mítico com o histórico e o social, e o saci-poeta ou o poeta-saci gilbertino saltita pelos sertões e rincões transvestido de poesia.

PalaVras-chave: Saci. Imaginário. Poesia. Gilberto Mendonça Teles. Mito.

\section{INTRODUÇÃO}

Este estudo apresenta alguns poemas e considerações sobre o livro Saciologia goiana (2016) do escritor goiano Gilberto Mendonça Teles, explorando na referida obra a figura mítica do Saci. Esse personagem

Doutorando em Letras na Universidade Estadual do Oeste do Paraná/UNIOESTE, Cascavel, Paraná, Brasil. Bolsista CAPES.

E-mail: vanderleikroin@gmail.com Orcid iD: https://orcid.org/0000-0002-2282-9923

* $\quad$ Professor Associado no Programa de Pós-Graduação em Letras da Universidade Estadual do Oeste do Paraná/UNIOESTE, Cascavel, Paraná, Brasil. Ministra aulas de Lírica e Sociedade e Literatura Comparada. Bolsista de Produtividade em Pesquisa da Fundação Araucária (Paraná). E-mail: adonicruz@gmail.com Orcid iD: https://orcid.org/0000-0002-4672-7542 
presente na cultura e imaginário popular brasileiro aparece com toda potência em Saciologia goiana. Neste universo poético, Teles dialoga com a tradição poética universal ao reconstituir na sua obra intertextualidades com outros poetas. Reinventa poeticamente o seu saudoso Goiás, reconstitui o espaço, a geografia, a cultura, os mitos, as lendas, os costumes, enfim, de sua terra natal e cria, como se alude, em trocadilho, já no título da obra, a ciência do Saci, a "saciologia” e, por meio dessa inferência, colocase como sujeito partícipe do espaço goiano, apresentando uma poética saudosa, que põe em diálogo simultânea e concomitantemente o espaço local goiano e outros lugares.

O professor, poeta e crítico literário Gilberto Mendonça Teles nasceu em Bela Vista de Goiás, em 1931. Com mais de 40 livros publicados, o autor possui Antologias Poéticas na França, Portugal, Itália, Romênia, Bulgária, EUA, entre outros países. Pertence à Academia de Ciências de Lisboa. Agraciado com inúmeros prêmios, recebeu em Portugal, em 1987, a Comenda do Infante D. Henrique. O livro Hora aberta (1986, $3^{\text {a }}$ edição dos Poemas Reunidos) reúne a obra poética do autor.

Alguns dos livros publicados por Gilberto Mendonça Teles são: Drummond, a estilística da repetição (1970, $1^{\text {a }}$ edição); Vanguarda européia e modernismo brasileiro (1972, 1a edição); A retórica do silêncio (1979, $1^{\text {a }}$ edição); A escrituração de escrita (1996); Contramargem (2002). A obra de Teles tem sido estudada em diversas universidades, em dissertações de mestrado e teses de doutorado. O livro A Plumagem dos nomes: Gilberto, 50 anos de literatura, organizado por Eliane Vasconcelos, reúne textos de vários autores em homenagem ao poeta, professor e crítico literário.

A obra tratada neste trabalho, Saciologia goiana, cuja primeira edição é de 1982, alcançou, em 2016, a oitava edição ${ }^{1}$, o que evidencia a

Saciologia Goiana. Rio de Janeiro: Civilização Brasileira/INL, 1982. Capa de Irene Peixoto e Márcia Cabral. Orelha de Mário da Silva Brito. 158 p.; 2a ed. Em Hora aberta (3 $3^{\mathrm{a}}$ ed. de Poemas reunidos, supra); 3a ed. Goiânia: Conselho de Cultura de Goiás, 1987; "Sacicatura" por Sílvio. Capa de Jair Pinto. 148 p.; 4a ed. aumentada. Goiânia: Agência de Cultura Pedro Ludovico Teixeira, 2001. Fortuna crítica da obra e Bibliografia Completa do Autor. Capa de Vitor Burton, 196 p.; 5 a ed. aumentada, na 4a ed. de Hora aberta, infra.; 6 ${ }^{a}$ ed. Goiânia: Kelps, 2004. A mesma capa da $4^{a}$ ed. 204 p.; $7^{a}$ ed. aumentada: Goiânia: Kelps/Secretaria de Cultura de Anápolis, 2013, 178 p. (TELES, 2016, p. 182). 
qualidade literária e importância do livro para o estado de Goiás e o cenário da literatura brasileira. As formas do imaginário são complexos temas na poesia de Gilberto Mendonça Teles, porque elas ocorrem entrelaçadas às abordagens do mítico e do social A construção poética e o projeto estético de Gilberto Mendonça Teles residem nos procedimentos e nas formas escolhidas e nas palavras-poesia-memória, com os seus versos marcados pela concentração intensa de uma linguagem esteticamente organizada.

A vida do poeta está intrinsecamente ligada e diluída ao espaço coletivo de sua terra (Goiás), portanto, transparece nos versos que cria. O poeta e a sua obra mantêm forte a questão do "local" em diálogo com outros espaços, tempos e poetas, como Drummond e Camões, por exemplo. Por este anseio e polimorfismo de Saciologia goiana, Teles é o poeta-saci, porque, tal qual o personagem mítico, inquieto, agitador e zombeteiro, o autor procura construir uma ponte que una os homens de todos os rincões e sertões do mundo. Teles é também, complementar e simultaneamente, o saci-poeta, porque sai de um espaço coletivo para melhor transfigurá-lo poeticamente. $\mathrm{O}$ distanciamento é o que lhe permite colher intelectivamente toda a gama de vivências passadas guardadas na memória e potencializá-las, esteticamente, pela força dos versos dos poemas.

\section{O mito do Saci e a obra Saciologia goiana}

Saciologia goiana forma um conjunto que, como sugere o título da obra, salienta a "ciência do Saci". Para além das paragens goianas, cumpre destacar que o mito do Saci é recente. Segundo Donato (1972), os primeiros registros de sua configuração no Brasil datam do século XIX. No excerto abaixo, utilizando as palavras do folclorista Câmara Cascudo, o referido autor traz caracterizado e descreve a figura do Saci:

Influência portuguesa com aclimatação nacional. Câmara Cascudo descreve-o: 'Pequeno negrinho com uma só perna, carapuça vermelha na cabeça, que o faz encantado, ágil, astuto, amigo de fumar cachimbo, de entrançar a crina de animais, depois de extenuá-los em correrias, 
durante a noite, anuncia-se pelo assobio persistente e misterioso, inlocalizável e assombrador. Pode dar dinheiro. Não atravessa água como todos os encantados. Diverte-se, criando dificuldades domésticas, apagando o lume, queimando alimentos, espantado gado, espavorindo os viajantes nos caminhos solitários.' (DONATO, 1972, p. 217)

A figura peralta do Saci personifica-se notoriamente no folclore brasileiro, tanto que se tem até o Dia do Saci, comemorado em 31 de outubro. Tal recorrência, além de estar presente no folclore e imaginário popular brasileiros, encontra-se em obras significativas da literatura brasileira, como em Saciologia goiana, do escritor Gilberto Mendonça Teles; em O Saci, livro infantil de Monteiro Lobato, publicado em 1921, além de aparecer em outras histórias do Sítio do Picapau Amarelo, criadas pelo escritor paulista. O Saci aparece ainda - desafiando a imaginação das crianças - em outras histórias infantis, como em Como nasceram as estrelas: doze lendas brasileiras, de Clarice Lispector, e é figura recorrente nas histórias da literatura infantil brasileira.

Descrito no folclore nacional como um ser negro de uma perna só, sempre fumando cachimbo e com um gorro vermelho na cabeça, o Saci é tido como travesso. Geralmente, ele surge em um característico redemoinho e desaparece assim como surge: inesperadamente. Do seu gorro mágico tira muitas "mandingas" e faz muitas proezas. Inquieta os viajantes solitários em lugares e estradas ermas, espreita fazendas isoladas, assusta os animais, enfim, cria a desordem e semeia inquietudes por onde passa.

Na obra de Gilberto Mendonça Teles, o Saci aparece como o herói goiano, ou melhor, o anti-herói que surge dos lugares mais recônditos das paragens goianas e se espraia nacional e universalmente, tal como a própria poesia, (incluindo-se aí a gilbertina), que mantém os pés nos locais mais ermos do sertão de Goiás, mas espraia-se em diálogo com outros espaços do mundo.

Nas palavras de Lima (2013), a obra Saciologia goiana é uma declaração de amor a Goiás, à fala, à mulher e às coisas do estado. A autora observa que a obra 
Saciologia goiana, de Gilberto Mendonça Teles (1982), é um canto de amor à língua portuguesa, instrumento de trabalho do poeta ao seu: Goiás. Tal como o maior nome da língua lusitana, Luiz Vaz de Camões, que amou a língua mãe como ninguém, cantou as glórias de sua terra, mostrou o heroísmo do seu povo e morreu amando seu país, Gilberto se vestiu de Camões para falar de sua terra natal e se torna Camongo, 'mistura de Camões e Goiás' (FERNANDES, 1983, p. 11). Saciologia goiana é, portanto, uma declaração de amor a Goiás, à fala, à mulher e às coisas de Goiás. Da mesma forma que Camões conta a história dos heróis lusitanos, Saciologia goiana fala, dos heróis (sem "agá”) de Goiás, com seus jeitos e seus ais. (LIMA, 2013, p. 75-76, grifo da autora)

O Saci gilbertino se confunde metaforicamente com a figura do próprio autor, poeta, transformando a mitologia, os "causos" do Saci por meio da linguagem poética e mostrando-os ao mundo. Lima (2013) observa essa relação íntima entre Saci e poeta, o saci-poeta que se evidencia potencialmente, transpassando ambos as fronteiras geográficas e linguísticas para alcançar e conquistar espaço em outras paragens. Dessa maneira,

O Saci, figura simbólica em toda obra, representará a esperteza, a malícia, a perspicácia e toda a sabedoria de Gilberto Mendonça Teles. Suas narrativas terão sabor de malícia, amor, sexo. $\mathrm{O}$ cio, a vontade extrema de deglutir a palavra como objeto afrodisíaco, buscando o prazer de e na linguagem, todo o prazer das palavras, da poesia, da língua portuguesa, de Goiás. A lenda do Saci, com todos os seus segredos, dará maior conotação mitológica à poesia de G. M. T., que não conhece fronteiras, nunca teve medo, atravessou todas as passagens que o poético exigiu. (LIMA, 2013, p. 77)

Gilberto poeta é como o Saci, não tem medo e desconhece fronteiras, conforme inferiu a autora ao final do excerto acima, pois levou Goiás, os seus mitos, lendas, cultura e geografia metaforizados em versos a outros recantos. Ao destacar a trajetória poética de Gilberto Mendonça Teles e 
discorrer sobre o seu poema intitulado "Hidrografia", Turchi (2007) tece a seguinte afirmação:

O poeta dos goianos, Gilberto Mendonça Teles, resume, em 'Hidrografia', poema de Saciologia goiana, os mitos originais de sua gente: 'Os rios de Goiás, além de rios/de verdade, têm peixes, bichos, lendas'. O Paranaíba é o rio que separa Goiás do Sul do país e nele se concentra toda a simbologia sagrada que o limite carrega no seu sentido primitivo. O além Paranaíba é, justamente, o espaço fora do Éden primitivo, transpor o Paranaíba é o início de uma viagem onde se misturam o medo do desconhecido e, ao mesmo tempo, o fascínio da aventura: 'no Paranaíba/o sentido da brecha, da viagem/ o princípio do além. (TURCHI, 2007, p. 164, grifo da autora).

Ir ao fundo das coisas, conhecê-las profundamente é característica do poeta. Por meio dos versos, que não revelam nada de pronto, Teles vai descortinando mundos e construindo-os linguisticamente, apresenta-os ao mundo, aos leitores.

Teles conhece muito bem as paragens mais escondidas de Goiás, por isso Turchi (2007) o denomina “o poeta dos goianos", pois, reiteradamente, salienta o vínculo estreito que mantém com o seu estado natal, com a sua gente, com a cultura, com as lendas, com os diversos lugares de Goiás. Isso não é aleatório, mas se estabelece pelo imaginário, como nos mostra Durand (2014, p. 61):

As estruturas verbais primárias representam, de alguma forma, os moldes ocos que aguardam serem preenchidos pelos símbolos distribuídos pela sociedade, sua história e situação geográfica. Reciprocamente, contudo, para sua formação todo símbolo necessita das estruturas dominantes do comportamento cognitivo inato do sapiens. Assim, os níveis "da educação" se sobrepõe na formação do imaginário: em primeiro lugar encontra-se o ambiente geográfico (clima, latitude, localizações continentais, oceânicas, montanhosas etc.), mas desde já regulamentado pelos simbolismos parentais da educação, o nível dos jogos (o lúdico) e das aprendizagens por último. E, finalmente, pelo nível 
que René Alleau denomina de "sintomático", ou o grau dos símbolos e alegorias convencionais determinados pela sociedade para a boa comunicação dos seus membros entre si. (DURAND, 2014, p. 91).

No poema abaixo, intitulado "Goiás”, tem-se um exemplo dessa ligação obra/autor, em que a primeira aparece como um filho em gestação, rebento que nasce longe de casa. $\mathrm{O}$ poema tem um tom de saudosismo, em que as lembranças se acentuam quando o eu lírico está distante de sua terra. Por outro lado, somente quando distante este mesmo eu poético consegue ter a consciência de que (também) faz parte do mundo e da cultura goiana. O distanciamento (e a saudade) é o que o faz refletir sobre a sua relação orgânica com sua terra.

\section{GOIÁS}

Só te vejo, Goiás, quando me afasto e, nas pontas dos pés, meio de banda, jogo o perfil do tempo sobre o rasto desse quarto-minguante na varanda

De perto, não te vejo nem sou visto.

$\mathrm{O}$ amor tem destes casos de cegueira: quanto mais perto mais se torna misto, ouro e pó de caruncho na madeira.

De perto, as coisas vivem pelo ofício do cotidiano - existem de passagem, são formas de rotina, desperdício, cintilações por fora da linguagem.

De longe, não, nem tudo está perdido.

Há contornos e sombras pelo teto.

E cada coisa encontra o seu sentido

na colcha de retalhos do alfabeto.

E, quanto mais te busco e mais me esforço, de longe é que te vejo, em filigrana, 
no clichê de algum livro ou no remorso

de uma extinta pureza drummondiana.

Só te vejo, Goiás, quando carrego

as tintas no teu mapa e, como um Jó,

um tanto encabulado e meio cego,

vou-te jogando em verso, em nome, em GO.

(TELES, 2016, p. 41-42)

Já no primeiro verso do poema, o eu lírico alerta "Só te vejo, Goiás, quando me afasto", corroborando a ideia de que somente quando longe consegue refletir conscientemente sobre as relações umbilicais que o unem à terra de Goiás. Isso porque, quando junto ao espaço goiano, integrado a ele e imerso em suas vivências, "enrolado" nos acontecimentos cotidianos, não se vê nada: há uma relação e sentimento de amor que cega, e, reciprocamente, não deixa ser visto, porque é apenas mais um ser componente comum do meio, sem nada que o destaque do todo; é o que se verifica nos dois primeiros versos da segunda estrofe: "De perto, não te vejo nem sou visto/ O amor tem deste casos de cegueira."

Na terceira estrofe, há a dificuldade de se escrever sobre o que está postado à frente; em outras palavras, falta o discernimento para captar o local e transformá-lo linguisticamente, tornando-se, assim, a atividade poética e o ofício de versejar comensuráveis, porque não são dotados de valor estético. Consequentemente, no dizer do eu lírico, o poema evidencia-se como exercício infrutífero, pois não traz potencializadas em sua essência as "cintilações por fora da linguagem". Essa estrofe é complementada pela quinta, que traz a intelectividade e a memória, as quais entram em jogo na feitura do poema.

Há o esforço intelectual e a busca na memória de lembranças e imagens que concorrem para a elaboração dos versos, além de um apelo à consagrada "musa" e à tradição literária de que se vale o poeta: a referência a Drummond exemplifica bem essa questão. Em contrapartida, há também o desígnio da palavra poética como símbolo de inter-relações humanas. Segundo Borges (2000), se, por um lado, a linguagem burilada 
do poema está imbricada no/pelo distanciamento, por outro, essa mesma linguagem poética precisa ter algo que é partilhado culturalmente para que signifique. Segundo o autor,

As palavras são símbolos para memórias partilhadas. Se uso uma palavra, então vocês devem ter alguma experiência do que esta palavra representa. Senão a palavra não significa nada para vocês. Acho que podemos apenas aludir, podemos apenas tentar fazer o leitor imaginar. O leitor, se for rápido o suficiente, pode ficar satisfeito com nossa mera alusão a algo. (BORGES, 2000, p. 122)

É esta imagem poética que deve ter um sentido para o leitor. Mais que alusões esparsas retiradas do poema, ele deve se identificar como partícipe da tessitura poética, em um jogo relacional íntimo, travado com o texto e com o autor.

$\mathrm{Na}$ quarta estrofe do poema "Goiás", é ao longe que o eu lírico confunde-se com o próprio poeta-saci, porque já consegue (ou conseguiu) extrapolar as fronteiras locais e explorar a grandeza de sua terra, registrando-a por meio da linguagem poética. "Cada coisa encontra seu sentido na colcha de retalhos do alfabeto". É a linguagem a dialogar com a memória, a história e as vivências de quem escreve e há tal intercorrência na poesia, porque, segundo Paz (1982), o homem é feito de palavras e se constrói social e culturalmente pela linguagem. De acordo com o crítico mexicano,

[...] A palavra é o próprio homem. Somos feitos de palavras. Elas são nossa única realidade, ou, pelo menos, o único testemunho de nossa realidade. Não há pensamento sem linguagem, nem tampouco objeto de conhecimento: a primeira coisa que o homem faz diante de uma realidade desconhecida é nomeá-la, batizá-la [...]. (PAZ, 1982, p. 37)

É, portanto, por meio da linguagem poética que o homem fala mais verdadeiramente de si e do mundo e, às vezes, precisa afastar-se de suas vivências culturais para que possa deixá-las aflorar mais coerentemente no poema que faz. É o que se verifica ainda nesta quarta estrofe de "Goiás", 
quando o eu lírico ressalta que, ao longe, "nem tudo está perdido”. Observase, no primeiro verso dessa estrofe, a necessidade do afastamento para se ter mais compreensão dos fatos e encontrar uma melhor maneira de imprimir uma imagem que seja verossímil e esteticamente válida.

Para finalizar, na última estrofe, há a ligação entre o poeta e a sua terra, a qual é sempre reavivada poeticamente e se mantém acesa para o eu lírico. De Norte a Sul, do mais aparente aos rincões distantes, Goiás aparece em imagens poéticas verso a verso, meticulosamente pensados, com a paciência de Jó. É assim que o eu lírico vê e pensa Goiás com maior propriedade, quando anda carregado do arcabouço da linguagem poética.

Oliveira (2007) destaca a "heterogeneidade discursiva" na construção poética gilbertina e tece considerações acerca da imagem simbólica do Saci intercalando-a aos espaços geográficos, sociais e políticos de Goiás:

É em Saciologia goiana que o poeta-saci subverte a ordem instituída. No 'risco' feito no papel, o poeta deixa o 'rastro'. Por onde passa deixa as suas 'marcas' como o próprio Saci que, remexe a terra, faz o seu redemoinho e desaparece, deixando várias marcas por todos os lugares onde passa. O poeta é aquele que 'remexe' na história de sua terra natal. E, ao colocar em reflexão uma série de problemas sociológicos, que são inerentes no Estado de Goiás, o escritor também coloca em 'cena' os problemas que são inerentes à história de nosso país. Nesse sentido, a poesia é uma fórmula utilizada pelo poeta para imaginar a nossa reação [...]. (OLIVEIRA, 2007, p. 375, grifo da autora).

Os fios da memória interligados às redes simbólicas e poéticas dos "rios discursivos", efetivados pela voz do poeta, ao cantar sua terra natal e o estado de Goiás, direcionam o olhar para uma configuração mais ampla, globalizadora no sentido dado à elevação do mito do Saci "goiano". É o poema a potencializar a história e a fazer um jogo com o que o circunda, pois há o entrelaçamento dos versos ao presente coletivo, ao mesmo tempo que a obra tende à atemporalidade. 
Teles (2005, p. 56), ao se referir à poesia e ao fazer poético, pontua que:

[...] Todo grande poeta sabe todos os segredos da sua arte, do passado ao presente, do popular ao clássico - o que lhe permite inventar a partir desse conhecimento - e assim escrevem, ora obedecendo à tradição (que eles conhecem), ora inventando novas maneiras e técnicas de dizer, e de escrever.

O ato de criação poética, conforme Teles (2005) expõe no excerto acima, está em estreito diálogo com as leituras feitas. Toda obra poética não se constrói no vazio, mas se estrutura em diálogos e relações que o poeta mantém com toda a literatura precedente. A partir dessas leituras, o poeta edifica sua própria obra. Burila a linguagem de modo a dar nova forma a determinado tema: inventa como vai dizer. A busca do poeta em sempre inovar o que escreve - orquestrando fórmulas de originalidade no que expõe em versos, desenvolvendo um estilo único e, fazer também de cada poema um objeto único - o tornam um sujeito atento aos acontecimentos do mundo, em constante inquietação, sempre a buscar o novo, a sondar os homens e suas reações e esmiuçá-las por meio da linguagem poética.

Do início ao fim do processo de criação, o poema também pode incutir a ideia de artefato. E justamente porque é também um trabalho consciente, intelectual, segundo Teles (2005), uma vez que o poeta simplesmente organiza linguisticamente as suas ideias e as expõe ao mundo. Segundo o autor,

O poema, que pode ter ou não poesia, não nasce pronto. Tem de ser feito pelo poeta: ele é um objeto verbal, e artístico. É possível que a ideia do poema e o seu tema estejam na cabeça do poeta. E o que o poeta faz é simplesmente expressar esse tema de maneira artística, a melhor que puder fazer. Às vezes se faz da primeira vez, outras - e é o comum - precisam de várias versões, até que o poeta fique contente com o que escreveu [...]. (TELES, 2005, p. 56) 
O exercício poético e a própria poesia concorrem para mostrar as diferenças do homem e do mundo e reiterar a liberdade, liberdade esta que cada vez mais o homem vai perdendo e a precisa exercitar, como um ponto de fuga, pela linguagem poética e artística, de maneira geral. Conforme Teles (2005, p. 62),

A poesia é por isso o exercício maior da nossa liberdade de ser: através dela tomamos contato com uma categoria de 'sagrado' que não é bem o sobrenatural, mas uma saída do comum, da linguagem comum que nos achata, que nos faz igual a todo mundo, que ilude a nossa individualidade. A liberdade de que falamos está na possibilidade de escolhermos as nossas palavras e de organizá-las segundo o nosso gosto, de investir nelas as significações mais caras às nossas emoções e ao nosso imaginário [...]. (TELES, 2005, p. 62, grifo do autor)

A poesia de Teles (re)evoca os espaços míticos, poéticos e sociais e tece configurações de um eu poético atento às observações da natureza circundante, instaurando um jogo de cumplicidade com o leitor, com vistas a uma poética da busca e das confluências mítico-sociais, relacionados ao eu-natureza-cosmo, efetuadas mediante a performance enquanto "ato de presença no mundo e em si mesma”, como assevera Zumthor (2014, p. 67). É o que se verifica no poema abaixo.

\section{GEOGRAFIA DO MITO}

O saci-passarinho é da pororoca:

canta sozinho, canta na maloca

e canta no oco d'alma do caboclo

da Amazônia.

O saci-ventania é do pastoreio:

venta a noite toda, venta no rodeio, venta na coxilha e inventa a fronteira da tropilha do Rio Grande.

O saci-goiano é do pererê: 
passa o ano todo junto de você, erguendo saia de moça dengosa, pulando cerca e contando prosa, ver redemoinho de poeira junto à porteira, numa perna só,

com seu lápis preto

$$
\text { fazendo soneto }
$$

de vento e cipó.

(Falo do saci como se falasse do saci-mandioca, do saci-fumo, do saci-mapa e seus apodos, como se alguém continuasse rindo à socapa e pulando sem rumo na memória de todos).

(TELES, 2016, p. 42-43)

Em "Geografia do mito" observa-se a figura mítica do Saci, cuja história extrapola as fronteiras espaciais, disseminando-se de Norte a Sul do país. Na primeira estrofe do poema, há a descrição do que seria o saci amazônico, o saci-passarinho, ser misterioso, que traz consigo em seu assovio o gorjear igualmente misterioso do solitário uirapuru, pássaro da floresta amazônica que se caracteriza pelo seu canto singular. Arredia, a ave não se deixa notar facilmente e o seu canto confunde e desorienta o ouvinte (homem) na mata. Há lendas que dizem que quando o uirapuru canta, toda floresta se cala. O mesmo faz o Saci, que, segundo o folclore, anuncia a sua chegada com assovios, barulho que também desorienta, pois denuncia a presença do negrinho, sem mostrar a sua localização. Dessa maneira, pode-se dizer que o saci-passarinho é (também) o uirapuru, que, quando chega deixa todos calados, aparvalhados e está igualmente presente nas lendas amazônicas, assim como as figuras misteriosas do boto, da iara etc.

Na segunda estrofe, a figura mítica está presente em outro espaço. $\mathrm{O}$ saci-ventania aparece agora como figurante das paragens gaúchas. Aparece 
nas coxilhas do Rio Grande do Sul, regiões de terrenos ondulados onde se pratica a pecuária, por isso se verifica "O saci-ventania é do pastoreio", no primeiro verso dessa estrofe. O Saci "venta a noite toda, venta no rodeio" ( $2^{\circ}$ verso), ou seja, remete à outra forma de o Saci se "materializar" ou aparecer, que é por meio do rugir do vento (do redemoinho) criado por ele mesmo. Então, o Saci é o vento (o minuano gaúcho), que sopra forte e deixa irrequietos os animais. Sendo vento, "venta na coxilha e inventa a fronteira da tropilha do Rio Grande”. Nesses versos, evidenciam-se as traquinagens do Saci no descampado gaúcho (pampas). Ao fazer suas estripulias, alvoroça as tropas de animais no campo, guiando-as e dispersando-as dos bandos (manadas) conforme lhe convém. As fronteiras que ele inventa à tropilha (e a vai guiando) é a direção do caos, como o vento que sopra de um lado a outro.

Oventoéelementomarcantedospampas.Aparecesignificativamente na obra de um dos maiores escritores rio-grandenses, Érico Veríssimo e, simbolicamente, significa mudanças. Assim como o gado e o cavalo, o traquino Saci se faz companhia do gaúcho dos campos, por isso, nessa segunda estrofe, o Saci é "do pastoreio" e é "vento". Obviamente, por sua natureza peralta, é um pastor inconsequente e a causa de uma ventania desordeira.

Denófrio (2005) destaca as imagens míticas do Saci, no sentido de que "[...] é Saciologia goiana, com a figura mítica do Saci saltando irreverente ao longo do texto, cantando o amor à terra, mas sobretudo afrontando os eróis (sem h) de Goiás, anagramatizados nos poemas.” (p. 85). Ao analisar, especificamente "Geografia do mito", o autor afirma que

[...] O poeta convoca, por região, todos os tipos de sacis: o saci-passarinho, que é da pororoca ou da Amazônia, o saci-ventania, que é do pastoreio ou do Rio Grande; o saci goiano ou do Pererê; o saci-mandioca, o saci-fumo; o saci-mapa, enfim, todos os sacis fálicos criados por GMT, mas sempre o saci [...]. (DENÓFRIO, 2005, p. 85)

É o Saci, sempre zombeteiro, presente em todas as regiões, a fumar o seu cachimbo e a tramar e orquestrar as suas brincadeiras de mau 
gosto. De feição maliciosa, está sempre em movimento. É seu natural esta inquietação, este constante deslocamento, como se o comodismo e sedentarismo fossem mortais e a morosidade o extinguisse, daí a necessidade de este arrebatar por onde passa (circula), quebrando o estado da ordem vigente e aparente; deixando um rastro de perguntas, podendo ser, de maneira mais ampla, um semeador de mudanças.

No poema "Descrição", há toda uma gama de nominação/descrição da imagem do Saci, em que o eu lírico faz referência às características da figura mítica, exponencialmente malandra.

\section{DESCRIÇÃO}

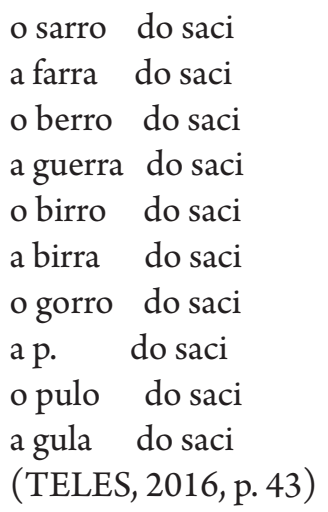

No primeiro verso, há o "sarro", deboche sarcástico que o ser mítico mostra de si para si ao contemplar as reações das pessoas diante de suas malandragens. A "farra", no verso seguinte, denota a diversão e satisfação egocêntrica do Saci ao operar o caos por onde passa. O "berro" é o símbolo do medo que ele impõe ao homem, o qual não consegue localizá-lo e essa dúvida lhe causa angústia, pois nunca sabe das intenções do ser.

A "guerra" do Sacié espalhar a confusão, é como a "guerra" travada nas relações adulto-criança, em que o primeiro rege a organização, enquanto a segunda está sempre a subverter (inconscientemente a ordem). Já que a figura do Saci é tida no imaginário popular como um menino "maroto", a sua diversão é afrontar a ordem social vigente estabelecida pelo adulto. 
Esta "guerra" é decorrente da "birra" do Saci, pois ele não compactua nunca com a ordem que lhe é imposta. Desgostoso com as normas, subverte-as e, da birra internalizada, transforma em guerra exteriorizada.

O "birro" e/ou "gorro" são, ao mesmo tempo, a invulnerabilidade do Saci. Esse objeto mágico é que lhe dá a particularidade de aprontar sem sofrer as sanções e castigos que lhe poderiam ser impostos. O vermelho, cor característica desse acessório, simboliza o vigor e, segundo Chevalier e Gheerbrant (2006), refere-se ao incitar de ações. É a imagem do ardor, das batalhas, do "Eros livre e triunfante" (p. 945). Dessa maneira, o Saci é associado comumente a um menino (criança travessa) cujo vigor está florescente e a "batalha" (ânsia) dele é fazer descobertas, instalar situações embaraçosas às pessoas para descobrir as reações e consequências de suas estripulias e traquinagens.

A "p." do Saci simboliza a estabilidade, potência e virilidade. Significa o falo, órgão sexual masculino. O "p", abreviado equivale a termos utilizados no linguajar popular (chulo), como "pinto" ou "pica”. Trata-se de equilíbrio, porque o Saci tem uma só perna, então lhe seria dificultoso aprontar se não tivesse as condições (físicas) essenciais. Isso se resolve com a "p", que lhe dá integralidade, equilíbrio e potência total para realizar suas manobras de moleque traquino.

O "pulo" pode denotar a capacidade do Saci para se livrar ou sumir de problemas desencadeados pelas suas próprias ações intempestivas. Ao pular, ele salta para longe de problemas, espreitando sempre ao longe o desfecho da confusão que ele mesmo causou. A "gula" é esta necessidade ou pulsão de sempre estar em movimento e desestabilizar os espaços, ou seja, o Saci é um ser em constantes deslocamentos, impulsionado pelo desejo de implantar a confusão. Saciada momentaneamente essa "gula" de aterrorizar determinado lugar, logo ele sai aos pulos procurando uma nova fonte para se "alimentar".

Outro poema presente em Saciologia goiana é "Ser tão Camões", que traz, já no título, o cenário em que aparece a figura mítica do Saci. Alude e faz intertextualidade com o poema épico de Camões, Os Lusíadas, com o diferencial de que as cenas nostálgicas descritas se passam no 
sertão goiano, enquanto a épica camoniana se desdobra nos mares. O Saci (implícito no poema de Teles) pode ser associado ao monstro (Gigante Adamastor) de Os Lusíadas. É a luta do homem, um pescador a se digladiar com uma figura que o vai cercando com suas estripulias ameaçadoras. Em "Ser tão Camões", equaliza-se o encontro do Gigante Adamastor com os marinheiros da esquadra de Vasco da Gama no mar, descrito em Os Lusíadas. No poema gilbertino, esse encontro épico é protagonizado pelo encontro de um pescador com o mítico Saci, em um rio, nas plagas goianas.

\section{SER TÃO CAMÕES}

$[\ldots]$

Primeiro, fez sumir os meus anzóis os beliscões dos peixes e sereias. Fez crescer a zoada dos mosquitos e a sensação de vento nos cabelos.

E me armou no mais íntimo do ser a máquina do medo, me ocultando o amoroso espetáculo dos botos e a legenda da lua nos remansos.

Depois, foi-me atirando as suas ondas, foi-me arrastando pela correnteza e me foi perseguindo na vazante, como o rio de Homero ou como aquele oculto e grande rio a que os indígenas chamaram de Araguaia, pronunciando o dialeto das aves que povoam os longos descampados.

Talvez sonhe

el-rei com seus dois rios de altas fontes. Talvez ouça o silencio das iaras dormindo nos peraus. E talvez chore toda aquela apagada e vil tristeza 
de quem penetra a solidão noturna

do canto da jaó, sem perceber

o discurso do rio que me grita

do barranco:

"Não passarás, Saci,

destes vedados términos. Goiás!

eis o sinal que vibrará canoro

e belicoso, abrindo na tua alma

vastidões e limites.

Terás sempre

O sal da terra e a luminosa sombra

Que te guia e divide, e te faz duplo,

Real e transparente, mas concreto

Nas tuas peripécias.

Nada valem

tua cabeça de mandinga, o aroma

de teu cachimbo e o mágico rubor

de tua carapuça. Nada vale

a tua perna fálica, pulando

nos cerrados.

Há vozes que te agridem

e dedos levantados te apontando

nas porteiras, nas grotas, na garupa

das éguas sem cabeça, como há sempre

uma tocaia, um canivete, um susto,

uma bala perdida que resvala

em tuas costas.

Mas ainda tens

de nutrir tua vida nas imagens

da terra. Ainda queres como nunca

alegres campos, verdes arvoredos,

claras e frescas águas de cristal

que bebes em Camões.

$$
[\ldots]
$$

como o rio de lendas que se cala- 
mitoso na linguagem.

(TELES, 2016, p. 47-49)

Pode-se fazer analogias entre o eu lírico (ou o próprio autor, Teles) com a figura de Camões. Aquele leitor deste. Ainda, pode-se associar o poeta-saci ou o saci-poeta (Gilberto Mendonça Teles) à própria figura mítica do Saci, para o qual o rio grita: "Não passarás, Saci, destes vedados términos. Goiás! Nesta chave de leitura está em jogo a própria disseminação e alcance da obra camoniana e de Teles, ambas ultrapassaram as fronteiras (de Portugal e Goiás). Se analisados, rapidamente, os mapas do estado de Goiás e de Portugal, nota-se certa similitude entre ambos, "a entranha dos mapas”, as fronteiras geográficas que guardam a riqueza cultural dos povos, o que também aproxima as duas obras referidas acima.

Para finalizar, há o mar português, exaltado por Camões e por Fernando Pessoa. A façanha do desbravamento do espaço marítimo pelos portugueses equivale a descortinar o sertão goiano, em sua vasta riqueza, proposto por Teles neste poema. O título sintetiza esse encontro: ser tão Camões, ou seja, reatualizar intertextualmente a obra do poeta português redimensionando-a pelas paragens goianas e mostrar a grandeza do sertão de Goiás e do sertão marítimo, ou seja, indicar esses espaços como extensos e misteriosos e instigar o homem a descobri-los, enfrentando seus perigos, lendas e medos. Há, assim, nessa intertextualidade, o relatar dos mitos, pois, como observa Durand (1983), por meio da literatura o mito se perpetua. Segundo o crítico do imaginário, se entrelaçam: “[...] visto que a linguagem mítica é uma linguagem literária. $\mathrm{O}$ mito conta-se [...]." (p. 27).

De acordo com Mello (2007), Teles salienta os espaços fronteiriços e as suas reconfigurações do sertão/mundo, como na passagem:

O texto que cenariza as tensões do entrelugar da cultura brasileira, interiorizadas no plano simbólico do poeta Mendonça Teles, como dilaceramento, objetiva e subjetivamente dado, é o poema "Ser tão Camões" 
(Saciologia goiana, 1982)2 . O enlace paradoxal das duas instâncias: o limite da regionalidade, e a vastidão do universal, compõem o dilema da alteridade que se faz antítese e se cumpre na síntese da complementaridade assumida, pelo homem/poeta, na desvelação do sujeito/ autoral e estado de escritura engajada. (MELLO, 2007, p. 395, grifo do autor)

Assim, a linguagem em Saciologia goiana projeta toda uma elaboração do fazer poético, com as suas imagens alicerçadas no ofício do verso e as relações míticas. Mello (2007, p. 395) assevera que

O sertão é o mundo, já nos disse Guimarães Rosa. Camões o mundo, sertão regionalidade, apenas nos reiteram que o universal está em nosso quintal. Mas entre o rio e o poeta faltava a mediação telúrica da nossa identidade em construção: o Outro representado de nós-interior capaz de transcender nosso individual em Dupla Voz. (MELLO, 2007, p. 395, grifo do autor)

Quando alude à saciologia e se apresenta também como poeta-saci em Saciologia Goiana, Teles vai além de mostrar lendas, histórias, lugares e culturas locais. Mostra a figura do Saci universalmente, porque esse ser, com as suas peraltices, tem alguma relação com outros seres míticos, de outros espaços e tempos, como por exemplo Dionísio, o deus grego conhecido pelos excessos e festas orgíacas.

No poema a seguir, evidencia-se quão entranhada está a simbologia cultural do Saci, ao qual se recorre em algumas situações, na esperança de, por meio das mandingas desse ser, obter soluções para problemas de saúde e, principalmente, resolver questões relacionadas ao amor:

\section{O SACI}

O negro chegou aos grotões e chamou pelo Saci, que de pronto apareceu.

- Toma lá a sua cabeça de mandinga, seu Saci,

2 TELES, Gilberto Mendonça. Saciologia goiana. Goiânia: AGEPEL, 2001. (Nota do autor). 
e dá-me cá o feitiço pra Sá Quirina.

$\mathrm{O}$ moleque desbarretou-se, tirou uma pitada grossa da cumbuca, fungou, e, entregando o resto a pai Zé, disse:

- Dá-lhe a cheirar esta pitada, que a crioula é sua escrava. E desapareceu, fungando, pulando no seu único pé nos grotões e covoados da roça.

(TELES, 2016, p. 170).

Nos versos de "O saci" delineia-se o encontro de um negro com a figura mítica do Saci. Aquele em busca de auxílio para "prender” uma mulher. Um encontro inusitado, uma vez que o Saci aparentemente não tem relações ordeiras de proximidade com o homem. No poema, as relações que ambos mantêm são estritamente de interesse: dá-se fumo e outras coisas à encapetada figura para se livrar de suas traquinagens.

Em "O saci" fica evidente a reclusão em que vive o Saci. Ele se recolhe aos "grotões", ou seja, o espaço do Saci remete a um lugar isolado, onde é difícil de o encontrar e longe para se chegar. Isso está relacionado diretamente ao "feitiço" que o negro busca. Pai Zé procura algo que se intui proibido ou imoral nas normas vigentes da sociedade e, portanto, só pode ser realizado por uma figura misteriosa, mística e às escondidas; em uma espécie de acordo secreto firmado em um lugar distante e oculto da vista de todos.

Nesse poema, entrelaçam-se cultura, sociedade, literatura e mito, Gilberto não as separa. Nesta perspectiva, ele dialoga com Durand (1983), que não designa como estanques cultura e sociedade. O crítico argumenta: “[...] Não separo as ciências da cultura, como a crítica literária e a literatura, das ciências da sociedade. Parece-me um disparate absoluto querer uma sociologia sem cultura." (p. 24). Assim, o sociólogo tem o mesmo ideal do poeta Gilberto, que coloca a sociologia em sua saciologia do saci.

Se o social está no Saci, o Saci está no imaginário social goiano e brasileiro como todas as suas mandigas e mistérios. Em "O saci", a cabeça do moleque saci é descrita pelo seu interlocutor como "cabeça de 
mandinga”, por causa de seu barrete vermelho, de onde o ser retira todas as suas magias. Por fim, o Saci atende ao pedido de pai Zé e desaparece saltitante, com a pressa de sair da vista do outro enquanto aquele ainda estivesse entretido com as instruções que o Saci lhe dera. Essa abrupta saída de cena ocorre do mesmo modo que ele apareceu ("de pronto") e não se sabe se o Saci de fato ajudou pai Zé ou apenas o enganou e fugiu, deixando o outro com a frustração que, se ocorreu, só será percebida posteriormente.

É o Saci a desaparecer assim que (aparentemente) soluciona o problema do seu interlocutor. Essa é, alusivamente, a mesma condição do poeta e do poema. Aquele se desgarra (afasta-se), de certa maneira da obra que criou. $\mathrm{O}$ poema toma vida própria porque vai falar universalmente ao mundo do seu mundo particular e esse mundo particular, no poema, tende, muitas vezes, mais a se camuflar do que transparecer explicitamente. Nesse sentido, para Paz (1991, p. 48), “[...] a obra não é uma coisa: é um leque de signos que, ao se abrir e fechar, nos deixa ver e nos oculta, alternativamente, seu significado. A obra de arte é um sinal de inteligência que o sentido e o sem-sentido trocam entre si [...]."

O sentido e o sem sentido a quealude $\operatorname{Paz}$ (1991) éa plurissignificação primordial da poesia. Ela se oculta e se mostra simultaneamente. Mostrase na tessitura linguística, mas não está irreversivelmente presa a esse tecido; nas entrelinhas há infinitamente mais coisas que o aparente. Nesse ato de o poético simultaneamente se ocultar e se mostrar, pode-se dizer que Saciologia goiana fala do universal pelo local e vice-versa. O poeta é enigmático, assim como é o simbólico Saci, cerne da referida obra. Ambos são equiparados por Fernandes (2005), que tece o seguinte registro sobre a obra gilbertina:

O canto mágico e enigmático do saci une-se ao engenho e à arte do poeta, para falarem da perna de outro saci: o Estado de Goiás, cujo mapa lembra a perna fálica do encapetado. ${ }^{3}$ Os disfarces do saci, agora, são

3 "Lembre-se que a semelhança existia antes de se proceder a criação do Estado de Tocantins". (Nota do autor). 
os sons das palavras, magicamente utilizadas pelo poeta. Como o conto do saci, o canto do poeta, em vez de revelar sua presença, encobre-o ainda mais, porque transformado em palavras. A arte e a ciência do saci são a arte e a ciência do poeta. (FERNANDES, 2005, p. 125)

Nesta passagem verifica-se novamente a comparação entre o Saci e o poeta, ou seja, sobre os disfarces dos quais ambos se valem para camuflar as respectivas presenças. É enigmática a poesia, porque não se deixa prender em leituras unívocas, renova-se e ressignifica a cada nova leitura; assim como o Saci, que não se deixa localizar, apenas faz sentir a sua presença pelo redemoinho e traquinagens diversas que forma ao seu redor quando chega a determinado lugar.

Dessa maneira, o poeta que, muitas vezes, foi caraterizado como mágico, como um deus, como alguém dotado de inteligência ímpar, em Teles, mais especificamente em Saciologia goiana, descortina-se como o popular e conhecido Saci, que, por sua vez, também pode ser considerado uma espécie às avessas de "deus" dos sertões e lugares ermos goianos. Essa figura representa, simbólica e metaforicamente, a essência do poeta e da sua poesia, que une o popular e o erudito.

\title{
ENTREVISTA
}

\author{
Abel: Como você explica o fato \\ de haver em Goiás \\ gente que gosta muito de você \\ e muita gente que o odeia? \\ Saci: Talvez porque na lua cheia \\ se conta muita potoca \\ e, além do quê, uso minhoca \\ na poesia.
}

(TELES, 2016, p. 147). 
Fica comprovado neste poema-entrevista ${ }^{4}$ que o poeta mergulha a fundo e se integra ao mito do Saci, realça o popular à sua poesia, fazendo um todo coerente, que coloca em diálogo Goiás e o mundo, aproxima história e mito, afrontando tradições, costumes, realçando críticas aos eróis (

Nada se cria do nada e nenhum discurso poético se sustenta por si mesmo. Teles mostra essa premissa em toda a sua obra. $\mathrm{O}$ mundo e o saci goiano mostrados em Saciologia goiana existem porque há a terra de Goiás e tudo o que a constitui, os sertões; existe também o poeta interessado em "poetar", descobrir esses lugares e figuras e trazer isso em versos. De forma concomitante, o poema se amarra ao criador e à terra, reinventando, também, a ambos.

\section{CONSIDERAÇÕES FINAIS}

A poesia fala da poesia das coisas, reverbera a poeticidade presente no mundo e mantém, ao mesmo tempo, um jogo intertextual com o vasto campo da poesia construído ao longo da história. É o que faz o poeta e crítico literário Gilberto Mendonça Teles na obra Saciologia goiana. Nela, o autor faz um jogo unindo tradição universal e localismo goiano, tecendo essa relação de maneira sutil, com alusões diversas, trocadilhos, jogo intertextual, inovações e neologismos.

A obra Saciologia goiana é como que um "tratado" que aproxima a figura do Saci à figura do poeta. Mostra que os recursos "saciológicos" desmelindres do Saci - são parecidos com os poéticos, porque pautados na relação visível-invisível, ou seja, as artimanhas do Saci tanto quanto do poeta caracterizam-se de ambiguidade e são multifacetadas. A essência da referida obra gilbertina mostra "o mundo todo ao mesmo tempo", enquanto o "essencial do saci", arraigado na cultura e imaginário popular mostra o mítico Saci arraigado "ao mesmo tempo em todos os lugares", ou seja, Teles procura mostrar universalmente o seu Saci por meio da

Este poema nasceu de uma entrevista que Gilberto Mendonça Teles concedeu ao professor Carlos Alberto dos Santos Abel, em 1991, conforme aponta Maria do Rosário de Morais Teles, em nota de rodapé (nota 98, p. 147), desta oitava edição de Saciologia goiana. 
saciologia que criou, ao mesmo tempo que estreita as relações com outras poéticas e traz o mundo para dialogar com a cultura saciológica de Goiás.

O diálogo entre o local e o universal casa-se perfeitamente neste livro de Gilberto Mendonça Teles. Ao fazer a sua cultura e regionalidade dialogarem com a tradição e habilmente fazer com que a sua poética trave relações com outros poetas ele cria uma obra instigante e saliente de originalidade, uma obra moderna por todos os recursos que utiliza, além de ser como que uma ode à sua terra natal, a qual é realçada, em seus inúmeros aspectos nos versos e poemas presentes em Saciologia goiana.

Myth and the imaginary in Saciologia goiana, by Gilberto

Mendonça Teles

\section{Abstract}

The aim of this paper is to explore the mythical character called Saci in the work Saciologia goiana, by Gilberto Mendonça Teles. This mythological creature, which is part of the our folklore, is present in legends and oral stories and is rooted in the popular imaginary of the Brazilian people and is the theme in Teles' book, which brings forth a real sociology of the Saci, drawing images of the mythical character in a dialogue with popular and scholar approaches. Such images are full of eroticism, social critic, satire, besides its rich intertextuality and allusions to other poets, in a rich dialogue that brings the sertão (Brazilian wilderness) of Goiás together with other spaces. In this book, filled with neologisms, allusions, experimentation, there is a junction between myth and history and with social aspects and the saci poet or Gilbertean saci poet who jumps around the sertões, dressed up with the enigma of poetry.

KeYwORDS: Saci. Imaginary. Poetry. Gilberto Mendonça Teles. Myth.

Mito e imaginario en Saciologia goiana, de Gilberto Mendonça Teles

\section{RESUMEN}

La propuesta de este trabajo es explotar la figura mítica del saci en la obra Saciologia goiana, de Gilberto Mendonça Teles. Este ser que hace parte del 
folclore, se sitúa en las leyendas e historias orales y está arraigado en el imaginario popular brasileño es tema de este libro de Teles, el cual presenta una verdadera sociología del saci, trayendo imágenes de este personaje mítico en diálogo con el popular y el erudito. Imágenes que están salpicadas de erotismo, de crítica social, de sátira, además de intertextualidad y alusiones a otros poetas, en un rico diálogo que acerca el agreste de Goiás con otros espacios. En este libro, lleno de neologismos, alusiones, experimentaciones, existe el encuentro del mítico con el histórico y con el social y el saci-poeta o el poeta-saci de Teles salta por las regiones agrestes, rincones, cambiado por el enigma de la poesía.

Palabras Clave: Saci. Imaginario. Poesía. Gilberto Mendonça Teles. Mito.

REFERÊNCIAS

BORGES, Jorge Luis. Esse ofício do verso. Organização Calin Andrei Mihailescu. Tradução José Marcos Macedo. São Paulo: Companhia das Letras, 2000.

CHEVALIER, Jean; GHEERBRANT, Alain et al. Dicionário de símbolos: mitos, sonhos, costumes, gestos, formas, figuras, cores, números. Coordenação Carlos Sussekind. Tradução Vera da Costa e Silva et al. 20. ed. Rio de Janeiro: José Olympio, 2006.

DENÓFRIO, Darcy França. O redemoinho do lírico: estudos sobre a poesia de Gilberto Mendonça Teles. Petrópolis: Vozes, 2005.

DONATO, Hernâni. Dicionário das mitologias americanas, incluindo as contribuições míticas africanas. São Paulo: Cultrix; Brasília: INL, 1972.

DURAND, Gilbert. Mito e sociedade: a mitanálise e a sociologia das profundezas. Tradução Nuno Júdice. Lisboa: A Regra do Jogo, 1983.

DURAND, Gilbert. $O$ imaginário: ensaio acerca das ciências e da filosofia da imagem. Tradução Renée Eve Levié. 6. ed. Rio de Janeiro: DIFEL, 2014. (Coleção Enfoques: Filosofia).

FERNANDES, José. O selo do poeta. Rio de Janeiro: Edições Galo Branco, 2005. LIMA, Maria de Fátima Gonçalves. Saciologia Goiana: o sentido da arte de a (r) mar o poema. Guará, Goiânia, v. 3, p. 75-89, jan./dez. 2013. 
MELLO, Joel Ferreira. Saciologia Gilbertina: Arte Universalizada de Seiva Regional e Fundões da Nacionalidade. In: VASCONCELLOS, Eliane (org.). A plumagem dos nomes: Gilberto 50 anos de literatura. Goiânia: Kelps, 2007. p. 159-167.

OLIVEIRA, Ilca Vieira de. O telúrico na poesia de Gilberto M. Teles. In: VASCONCELLOS, Eliane (org.). A plumagem dos nomes: Gilberto 50 anos de literatura. Goiânia: Kelps, 2007. p. 371-376.

PAZ, Octavio. O arco e a lira. Tradução Olga Savary. Rio de Janeiro: Nova Fronteira, 1982.

PAZ, Octavio. Convergências Ensaios sobre arte e literatura. Tradução Moacir Werneck de Castro. Rio de Janeiro: Rocco, 1991.

TELES, Gilberto Mendonça. Saciologia goiana. 8. ed. Anotações de Maria do Rosário de Morais Teles. Goiânia: Kelps, 2016.

TELES, Gilberto Mendonça. Sortilégios da criação. Rio de Janeiro: Edições Galo Branco, 2005.

TURCHI, Maria Zaíra. Gilberto Mendonça Teles: professor emérito da Universidade Federal de Goiás. In: VASCONCELLOS, Eliane (org.). A plumagem dos nomes: Gilberto 50 anos de literatura. Goiânia: Kelps, 2007. p. 159-167.

ZUMTHOR, Paul. Performance, recepção, leitura. Tradução Jerusa Pires Ferreira e Sueli Fenerich. São Paulo: Cosac Naify, 2014.

Submetido em 09 de fevereiro de 2021

Aceito em 17 de abril de 2021

Publicado em 19 de setembro de 2021 